\title{
Assays of nucleosome assembly and the inhibition of histone acetyltransferase activity. (13) Ligation-mediated single-sided PCR (LMPCR)
}

\author{
Takahito Yamasaki \\ RIKEN BRC \\ Takehide Murata \\ RIKEN BRC \\ Chunyuan Jin \\ RIKEN BRC \\ Kohsuke Kato \\ Tsukuba University \\ Michiya Noguchi \\ RIKEN BRC \\ Koji Nakade \\ RIKEN BRC \\ Jianzhi Pan \\ RIKEN BRC \\ Kyousuke Nagata \\ Tsukuba University \\ Kazunari Yokoyama \\ RIKEN BRC
}

\section{Method Article}

Keywords: histone chaperone, nucleosome assembly, inhibition of HAT, transcription factor, AP-1

Posted Date: July 30th, 2007

DOI: https://doi.org/10.1038/nprot.2007.341

License: @ (i) This work is licensed under a Creative Commons Attribution 4.0 International License. Read Full License 


\section{Abstract}

\section{Introduction}

We can use PCR to amplify segments of DNA located between two specified primer-hybridization sites. Single-sided PCR requires specification of only one primer-hybridization site, with the second being defined by the ligation-based addition of a unique DNA linker. This linker, together with the flanking genespecific primer, allows the amplification by PCR of any fragment of DNA. Because a defined sequence of discrete-length is added to every fragment, complex populations of DNA, such as sequence ladders, can be amplified intact with retention of single-base resolution. In this method, cleaved DNA is denatured and a gene-specific primer $\backslash$ (primer 1$)$ is annealed to the region of interest. During first-strand synthesis, this primer is extended by a processive polymerase $\backslash($ Vent DNA polymerase) to the cleavage site, to create a blunt end. DNA ligase catalyzes the attachment of a unidirectional $\backslash$ (staggered) linker to this blunt end. The 3 '-end of the longer strand of the linker is ligated to the $5^{\prime}$-end of the genomic DNA. The shorter strand of the linker lacks a 5 '-phosphate and, therefore, it is not ligated to the extension product of the gene-specific primer. The DNA is denatured and ligated to the extension product of the gene-specific primer. The DNA is denatured and a second gene-specific primer $\backslash$ (primer 2) is annealed to the genomic DNA and extended, by Vent DNA polymerase, through the ligated linker region. The extended product is now a suitable substrate for PCR: at one end, there is a linker sequence to which a linker primer can anneal and, at the other end, there is a genomic sequence to which a gene-specific primer can anneal. Only molecules that have both sequences will be exponentially amplified during subsequent PCR; molecules with only one of the sequences will be linearly, as distinct from exponentially, amplified. For the last extension, a third genespecific primer $\backslash$ (primer 3) that overlaps the second is used to label the DNA indirectly. The end-labeled extension products are visualized on a sequencing gel $^{1}$. For a detailed introduction to assays of nucleosome assembly and the inhibition of histone acetyltransferase activity, please go here: "http://www.natureprotocols.com/2007/07/30/assays_of_nucleosome_assembly.php":http://www.natureprotocols.com/2007/07/30/assays_of_nucleosome_

\section{Reagents}

Ligation-Mediated Single-Sided PCR This method involves single-sided PCR that initially requires specification of only one primer by modification site; the second primer is defined by the ligation-based addition of a unique DNA linker. This linker, together with the flanking gene-specific primer, allows exponential amplification of any fragment of DNA. $\otimes 0.4 \mu \mathrm{g} / \mu$ l Cleaved genomic DNA in TE buffer $\backslash(\mathrm{pH} 7.5) \otimes 4 \mathrm{dNTP} \operatorname{mix} \backslash(\mathrm{pH} 7.0), 25 \mathrm{mM} \backslash(25 \mathrm{mM} \mathrm{dATP}, 25 \mathrm{mM} \mathrm{dCTP}, 25$ $\mathrm{mM}$ dATP and $25 \mathrm{mM}$ dTTP, together, yield the $25 \mathrm{mM} 4 \mathrm{dNTP}$ mix, which is stored at $-20{ }^{\circ} \mathrm{C}$ ) $5 \mathrm{x}$ Amplification Buffer $\nabla 200 \mathrm{mM} \mathrm{NaCl} \otimes 100 \mathrm{mM}$ Tris-HCl $\backslash(\mathrm{pH}$ 8.9), at room temperature $\nabla 25 \mathrm{mM} \mathrm{MgSO}_{4} \otimes 0.05 \%$ Gelatin \(from bovine skin; Sigma-Aldrich Co.; cat. no. G9382) $₫ 0.5 \%$ Triton X-100 \(Sigma-Aldrich Japan;

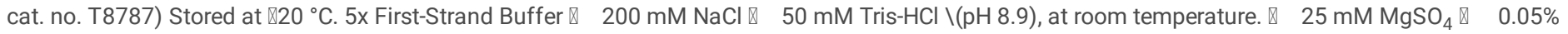
Gelatin Stored at $\otimes 20^{\circ} \mathrm{C}$. First-strand synthesis mix, per reaction $\backslash(25 \mathrm{ml})$ : $\otimes \quad 6.0 \mu \mathrm{l}$ of $5 \mathrm{x}$ first-strand buffer $\otimes \quad 0.3 \mu 1$ of $1 \mathrm{pmol} / \mathrm{ml}$ oligonucleotide primer $1 \mathrm{~L}$ $0.25 \mu 1$ of $25 \mathrm{mM} 4 \mathrm{dNTP} \operatorname{mix} \backslash(\mathrm{pH} 7.0) \otimes 23.2 \mu 1$ of $\mathrm{ddH}_{2} \mathrm{O} \otimes 0.25 \mu \mathrm{l}$ of $2 \mathrm{U} / \mathrm{ml}$ DNA polymerase from _Thermococcus litoralis_ $\backslash($ Vent DNA polymerase; New England Biolabs; cat. no. 254L) Note: Prepare solutions immediately prior to use. Mix all components except Vent DNA polymerase and chill on ice. Then add the polymerase and keep the mixture on ice. $₫$ Oligonucleotide forward primer 1: 5'-GTCCGCGGACGACCAGGTT AGCCGAGT-3'. 20 mM Unidirectional linker mix. $\nabla 20$ mM oligonucleotide LMPCR-1 \(see below) $\nabla 20$ mM oligonucleotide LMPCR-2 \(see below) $\nabla 250$ mM Tris-HCl \(pH 7.7) LMPCR-1: 5'GCGGTGACCCGGGAGATCTGAATTC-3' \(top strand) LMPCR-2: 5'-P-GAATTCAGATCT-3' \(bottom strand). Prepare this mix in advance as follows: $\backslash$ (1) purify the oligonucleotides on denaturing polyacrylamide gels; $\backslash(2)$ combine the two oligonucleotides in $250 \mathrm{mM} \mathrm{Tris-} \mathrm{HCl} \backslash(\mathrm{pH} 7.7)$ and heat for $5 \mathrm{~min}$ at $95^{\circ} \mathrm{C}$; $\backslash(3)$ transfer the mixture to $70^{\circ} \mathrm{C}$ and cool gradually for approximately $1 \mathrm{~h}$ to room temperature; $\backslash(4)$ allow the mixture to stand for $1 \mathrm{~h}$ at room temperature and then cool it gradually for approximately $1 \mathrm{~h}$ to $4^{\circ} \mathrm{C}$; and $\backslash(5)$ allow mixture to stand for approximately $12 \mathrm{~h}$ at $4{ }^{\circ} \mathrm{C}$ and store in aliquots at $-20^{\circ} \mathrm{C}$. Thaw linker mix on ice before use. Ligase dilution solution, per reaction $\backslash(20 \mu \mathrm{l}): \otimes 2.2 \mu \mathrm{l}$ of $1 \mathrm{M}$ Tris- $\mathrm{HCl} \backslash(\mathrm{pH} 7.5)$, at room temperature $\otimes 0.35 \mu \mathrm{l}$ of $1 \mathrm{M} \mathrm{MgCl}{ }_{2} \backslash($ final, 17.5 $\mathrm{mM}) \otimes 1.0 \mu \mathrm{l}$ of $1 \mathrm{M}$ DTT \(final, $50 \mathrm{mM}) \otimes 0.25 \mu \mathrm{l}$ of $10 \mathrm{mg} / \mathrm{ml}$ BSA \(DNase-free; GE Healthcare Bio-Science AB, Uppsala, Sweden) $\otimes 16.2 \mu \mathrm{ddH} \mathrm{H}_{2} \mathrm{O}$ Prepare immediately before use and chill on ice. Ligase mix, per reaction $\backslash(25 \mathrm{ml}): \nabla 0.25 \mu \mathrm{l}$ of $1 \mathrm{M} \mathrm{MgCl}_{2} \backslash(\mathrm{final}, 10 \mathrm{mM}) \otimes 0.5 \mu \mathrm{l}$ of $1 \mathrm{M} \mathrm{DTT} \backslash(\mathrm{final}, 20 \mathrm{mM}) \otimes 0.75 \mu \mathrm{l}$ of $100 \mathrm{mM}$ ATP $\backslash(\mathrm{pH} 7.0$; GE Healthcare Bio-Science AB; final, $3 \mathrm{mM}) \otimes 17.5 \mu$ l of ddH2O $\otimes 5.0 \mu \mathrm{l}$ of $20 \mathrm{mM}$ unidirectional linker mix $\backslash[\mathrm{final}, 4 \mu \mathrm{M}$ linker and 50 $\mathrm{mM}$ Tris- $\mathrm{HCl} \backslash(\mathrm{pH} \mathrm{7.7)]} \otimes 1.0 \mu \mathrm{l}$ of 3 Weiss units/ $\mu \mathrm{l} \mathrm{T4}$ DNA ligase $\backslash($ final, 30 units) Prepare immediately before use. First mix the solutions of MgCl 2 , DDT, ATP,

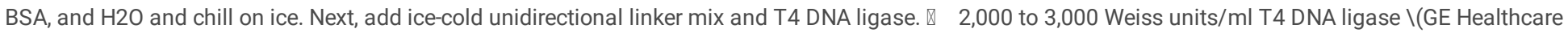
BioScience $A B) \otimes \quad 100 \%$ Ethanol, ice-cold at room temperature $\square \quad 75 \%$ Ethanol at room temperature $₫$ Amplification mix containing unidirectional linker primer mix and primer $1 \otimes 2 \mathrm{U} / \mu \mathrm{l}$ Vent DNA polymerase mix per reaction $\backslash(3.0 \mathrm{ml})$ Mix $0.6 \mu \mathrm{l}$ of $5 \mathrm{x}$ amplification buffer with $19 \mathrm{ml}$ of $\mathrm{H}_{2} \mathrm{O}$ and chill for several minutes in an ice-water bath. Add $0.5 \mu$ l Vent DNA polymerase $\backslash$ (see above), mix gently and return to ice-water bath. Prepare immediately prior to use. $\square$ Mineral oil \(Sigma-Aldrich Co.; cat. no. M5904) $\otimes$ Precipitation mix per reaction $\backslash(9.4 \mu \mathrm{l})$ : $\nabla 8.4 \mu \mathrm{l}$ of $3 \mathrm{M}$ sodium acetate $\backslash(\mathrm{pH} 7.0) \backslash($ final, $2.7 \mathrm{M}) \otimes 1.0 \mu \mathrm{l}$ of 10 $\mathrm{mg} / \mathrm{ml}$ yeast tRNA $\backslash(\mathrm{final}, \sim 1 \mathrm{mg} / \mathrm{ml}$ ) Prepare immediately before use. End-labeling mix. containing end-labeled primer 3 , per reaction $\backslash(5 \mathrm{ml})$ : $\otimes 1.0 \mu \mathrm{l}$ of $5 \mathrm{x}$ amplification buffer $\nabla 2.3 \mu \mathrm{l}$ of $1 \mathrm{pmol} / \mathrm{ml}$ end-labeled primer $3 \otimes 0.4 \mu \mathrm{l}$ of $25 \mathrm{mM} 4 \mathrm{dNTP} \operatorname{mix} \backslash(\mathrm{pH} 7.0) \otimes 0.8 \mu \mathrm{l}$ of ddH $\mathrm{H}_{2} \mathrm{O} \otimes 0.5 \mu \mathrm{l}$ of $2 \mathrm{U} / \mathrm{ml}$ Vent DNA polymerase $\backslash$ (see above) Prepare immediately prior to use. Mix the first four components and chill on ice before adding Vent DNA polymerase. Then chill and keep on ice. QVent DNA polymerase stop solution $\backslash(295 \mu \mathrm{l})$ : $\otimes 25 \mu \mathrm{l}$ of $3 \mathrm{M}$ sodium acetate $\backslash(\mathrm{pH} 7.0$; final, $260 \mathrm{mM}) \otimes 266 \mu \mathrm{l}$ of TE buffer $\backslash(\mathrm{pH} 7.5$; final, $10 \mathrm{mM}$

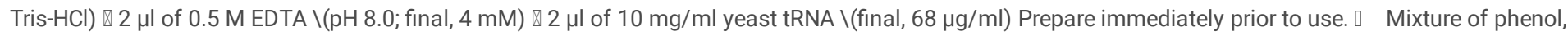
chloroform and isoamyl alcohol $\backslash(25: 24: 1 ; \mathrm{v} / \mathrm{v}) \square \quad$ Automated thermal cycler Ligation-Mediated Polymerase Chain Reaction $\backslash($ LM-PCR) Ligation to the extension product is allowed to proceed for $16 \mathrm{~h}$ at $16^{\circ} \mathrm{C}$ and is followed by PCR with gene-specific primers $\backslash\left(\right.$ primer $2,5^{\prime}$ -

GGTTGGCCAAGTCCGTCCGTCTGTCTGTCT-3'; and primer 3, 5'-TGGCCAAGTCCGTCCGTCTGTCTGTCTGTC-3') and the top-strand adaptor primer $\backslash($ LMPCR-1).

\section{Procedure}

1. Transfer $2 \mu \mathrm{g} \backslash(5 \mathrm{ml})$ of cleaved $\backslash$ (genomic) DNA to a silanized $1.5-\mathrm{ml}$ microcentrifuge tube and chill for several minutes in an ice-water bath. 2 . Prepare the first-strand synthesis mix that contains primer 1 and chill for several minutes in an ice-water bath. Add $25 \mu$ of this mix to the DNA sample, with gentle mixing 
with a pipette, and return the sample to the ice-water bath. Place "lid-locks" on samples to prevent tubes from popping open during denaturation $\backslash($ see Note 1). 3. Denature the DNA for $5 \mathrm{~min}$ at $95^{\circ} \mathrm{C}$; allow the primer to anneal for $30 \mathrm{~min}$ at $60^{\circ} \mathrm{C}$, and allow extension to proceed for $10 \mathrm{~min}$ at $76{ }^{\circ} \mathrm{C}$. As first-strand synthesis proceeds, prepare solutions for step $4 \backslash$ (see Note 2). 4. Thaw $20 \mathrm{mM}$ unidirectional linker mix in an ice-water bath. Prepare the ligase dilution solution and prepare the partial ligase mix \(minus the unidirectional linker and T4 DNA ligase). Chill both solutions in an ice-water bath \(see Note 23 ). 5. When the extension in step 3 is complete, immediately transfer the sample to the ice-water bath. Microcentrifuge the tube briefly at $4{ }^{\circ} \mathrm{C}$ to collect any condensate and then return it to the ice-water bath $\backslash$ (see Note 4). 6 . Finish preparing the ice-cold ligase mix mentioned in step 4 by adding the unidirectional linker mix, mixing, and adding T4 DNA ligase, in the ice-water bath $\backslash($ see Note 5). 7. Add $20 \mu$ l of ice-cold ligase dilution solution from step 6 to the sample, mix gently with a pipette, and return to the ice-water bath. Microcentrifuge the tube briefly at $4{ }^{\circ} \mathrm{C}$ and incubate overnight in a water bath at $16{ }^{\circ} \mathrm{C} \backslash($ see Note 6$) .8$. Prepare the sample for precipitation by placing in the ice-water bath for several minutes. Microcentrifuge the tube briefly at $4{ }^{\circ} \mathrm{C}$, then return to the ice-water bath $\backslash$ (see Note 7). 9. Prepare and chill the salt mix for precipitation. Add $9.4 \mathrm{ml}$ of ice-cold precipitation salt mix to the sample. Then add $220 \mu \mathrm{l}$ of ice-cold $100 \%$ ethanol. Mix thoroughly by inversion and chill for more than $2 \mathrm{~h}$ at $\otimes 20^{\circ} \mathrm{C}$. 10 . Pellet the precipitate by mirocentrifugation for 15 min at $4{ }^{\circ} \mathrm{C}$ and discard supernatant. 11. Add $500 \mu \mathrm{l}$ of room-temperature $75 \%$ ethanol and wash the pellet and walls of the tube. Microcentrifuge the sample for 5 min at room temperature and discard the supernatant. Remove the last traces of ethanol with a pipette and allow any remaining ethanol to evaporate by air drying or using a vacuum evaporator. 12. Add $70 \mu \mathrm{l}$ of double-distilled $\mathrm{H}_{2} \mathrm{O}$ and allow sample to stand at room temperature to dissolve the pellet. Agitate the tube occasionally to help the sample dissolve and, after each agitation, collect droplets by microcentrifugation for 2 to 3 sec. When the pellet has dissolved $\backslash$ (usually within 30 min or less), chill the sample in an ice-water bath. While the pellet is dissolving, prepare and chill the amplification mix that contains linker primer and primer 2. 13. Add $13 \mu \mathrm{l}$ of ice-cold amplification mix to the sample, mix gently with a pipette, and return the sample to the ice-water bath. 14 . Add $3 \mu \mathrm{I} \backslash(1 \mathrm{U})$ of Vent $\mathrm{DNA}$ polymerase mix to the sample and mix carefully with a pipette. Return the sample to the ice-water bath. 15 . Cover the sample with $90 \mu$ of mineral oil, microcentrifuge for a few seconds at $4{ }^{\circ} \mathrm{C}$, and return to the ice-water bath. 16 . Carry out 18 cycles of PCR, with the first denaturation for 3 to 4 min at $95{ }^{\circ} \mathrm{C}$, and subsequent denaturations for $1 \mathrm{~min}$. Allow primers to anneal for $2 \mathrm{~min}$ at a temperature 0 to $2^{\circ} \mathrm{C}$ above the calculated melting temperatures $\backslash(\mathrm{Tms})$; if primer 2 and linker primer have different Tms, use the lower Tm. Extend for $3 \mathrm{~min}$ at $76^{\circ} \mathrm{C}$. Then, for every cycle, add an extra $5 \mathrm{sec}$ to the extension step. Allow final extension to proceed for $19 \mathrm{~min}$. Transfer the sample to the ice-water bath, remove the "lid-lock" $\backslash$ (if applicable), and microcentrifuge briefly at $4{ }^{\circ} \mathrm{C}$ to collect any condensate. Keep the sample in the ice-water bath $\backslash$ (see Note 8). 17. Prepare the end-labeling mix that contains radiolabeled primer 3 and chill for several minutes in the ice-water bath. Add $5 \mu$ l of this mix to the sample. Mix aqueous phases by gently pipetting them up and down, keeping the sample on ice as much as possible. Microcentrifuge for a few seconds at $4^{\circ} \mathrm{C}$ and return to the ice-water bath. 18. Carry out two rounds of PCR to label the DNA. Perform the first denaturation for 3 to $4 \mathrm{~min}$ at $95^{\circ} \mathrm{C}$ and the second for $1 \mathrm{~min}$ at $95^{\circ} \mathrm{C}$. Anneal end-labeled primer 3 for 2 min at a temperature that is 0 to $2{ }^{\circ} \mathrm{C}$ above its calculate $\mathrm{Tm}$. Allow extension to proceed for $10 \mathrm{~min}$ at $76^{\circ} \mathrm{C}$. When the second extension is complete, transfer the sample to the ice-water bath. 19 . Place sample at room temperature and immediately add $295 \mu \mathrm{l}$ of Vent DNA polymerase stop solution. Mix on the vortex mixer. Microcentrifuge the tube for a few seconds to collect radioactive droplets from the top and sides of the tube. Add $500 \mu \mathrm{l}$ of the mixture of phenol, chloform and isoamyl alcohol and mix either by vigorous shaking or on a vortex mixer. Microcentrifuge for 3 to $5 \mathrm{~min}$ at room temperature. Transfer the upper aqueous layer $\backslash(\sim 400 \mu$ l; avoid the interface, if any) to a clean, silanized 1.5-ml microcentrifuge tube and mix thoroughly. Microcentrifuge briefly to collect droplets from the sides of the tube. 20 . Set up four clear, siliconized $1.5-\mathrm{ml}$ microcentrifuge tubes and add $235 \mu \mathrm{l}$ of room-temperature $100 \%$ ethanol to each tube. Transfer $94 \mu \mathrm{l}$ of the aqueous layer into each tube and mix thoroughly on the vortex mixer. Then chill for $22 \mathrm{~h}$ at $₫ 20^{\circ} \mathrm{C}$. Discard any remaining aqueous layer. 21 . Microcentrifuge the chilled samples for 15 min at $4{ }^{\circ} \mathrm{C}$ and discard supernatants. 22. Add $500 \mu$ of room-temperature $75 \%$ ethanol to each tube, mix on a vortex mixer, microcentrifuge samples for 5 min at room temperature, and discard supernatants. Remove the last traces of ethanol with a pipette and allow any remaining ethanol to evaporate by air-drying or by using a vacuum evaporator. 23. Add $7 \mu$ of loading buffer to each tube and allow tubes to stand at room temperature while pellets are dissolving. 24 . Denature samples for $5 \mathrm{~min}$ at $85^{\circ} \mathrm{C}$ to $90^{\circ} \mathrm{C}$. Load the entire contents of each tube on a $6 \%$ sequencing gel. After electrophoresis, fix and dry the gel, then autoradiograph the gel for 6 to $24 \mathrm{~h}$ without an intensifying screen. 25. As a control for LMPCR, prepare genomic DNA for LMPCR-aided direct genomic sequencing and sequence the DNA by chemical methods, as described elsewhere ${ }^{1-5}$. 1 . Fix, for example, F9 cells $\backslash\left(1 \times 10^{7}\right)$, which have been stably transfected with either pcDNA or wild-type JDP2-encoding plasmids, with 1.1\% formaldehyde for $30 \mathrm{~min}$ at room temperature. 2. Harvest cells and prepare mononucleosomes as described above. 3. In some cases, permeabilize F9 cells ${ }^{2}$ and digest partially with micrococcal nuclease $\backslash(\mathrm{MNase}$; at $30 \mathrm{U}$, $15 \mathrm{U}, 7.5 \mathrm{U}$ and $0 \mathrm{U}$ per reaction mixture), and then purify genomic DNA. 4. Perform cleavage mapping of MNase-digested DNA by Southern blotting analysis using a $\backslash$ $\left[{ }^{32} \mathrm{P}\right]$-labeled DRE oligonucleotide as probe. 5. Purify mononucleosomal DNA with a gel extraction kit $\backslash($ Qiagen GmbH; Hilden, Germany) according to the protocol from the manufacturer, with subsequent primer extension. 6. Perform the primer extension reaction as described above. 1. To demonstarate our method, we used the adapters LMPCR-1 and LMPCR-2 $\backslash$ (see above for sequences). 2. Ligation to the extension product was allowed to proceed for $16 \mathrm{~h}$ at 16 ${ }^{\circ} \mathrm{C}$ and was followed by PCR with gene-specific primers 2 or $3 \backslash$ (see above for sequences) and the top-strand adaptor primer $\backslash($ LMPCR-1). 3. The extended products were fractionated on a sequencing gel $\backslash(6 \%$ acrylamide) beside with DNA sequencing reactions that provided size markers $\backslash($ see Figure 5$)$.

\section{Critical Steps}

1. When mixing with a pipette, three or four careful strokes are usually sufficient. Try to avoid splashing the sample while mixing. 2 . First-strand synthesis is most easily performed in an automated thermal cycler. It is important that the DNA be completely denatured so that the primer can anneal. For this reason, it is a good idea to check the calibration of the thermal cycler. The extension step creates a blunt-ended substrate for the subsequent ligation reaction; therefore, success at this step is absolutely crucial because it determines the molecules that will ultimately be amplified. 3. Do not add unidirectional linker mix and T4 DNA ligase to the ligase mix until step 6. 4. The samples should be kept cold during steps 6, 7 and 8 to minimize the activity of Vent polymerase. 5. This order of addition is important because the unidirectional linker is prepared in $250 \mathrm{mM}$ Tris- $\mathrm{HCl} \backslash(\mathrm{pH} 7.7)$, which is required for ligase activity. 6. Addition of ligase dilution solution converts the first-strand synthesis mix into a solution compatible with the activity of T4 DNA ligase \(the concentration of NaCl and, more importantly, the $\mathrm{pH}$, are reduced.). Addition of the ligase mix provides a convenient method for the addition of ligase and linker to each sample. 7. Placing samples in the ice-water bath provides a convenient method for transfering them from the $16^{\circ} \mathrm{C}$ bath to the $4{ }^{\circ} \mathrm{C}$ microcentrifuge without warming them. 8 . An 
important parameter during this step is the temperature of denaturation. If it is too low, no signal or a shortened sequence ladder will result; if it is too high, the polymerase will be destroyed.

\section{References}

1. Lomvardas, S. \& Thanos, D. Modification of gene expression programs by altering core promoter chromatin architecture._Cell_**110**, $261-271 \backslash(2002)$. 2. Pfeifer, G. P. \& Riggs, A. D. Chromatin differences between active and inactive X chromosomes revealed by genomic footprinting of permeabilized cells using DNase I and ligation-mediated PCR._Genes Dev._ ${ }^{\star \star} 5{ }^{\star \star}, 1102-1113 \backslash(1991)$. 3. Pfeifer, G. P., Stigerwald, S. D., Mueller, P. R., Wold, B. \& Riggs, A. D. Genomic sequencing and methylation analysis by ligation-mediated PCR. _Science_**246**, 810-813 \(1989). 4. Ganity, P. A. \& Wold, B. J. Effects of different DNA polymerases in ligation-mediate PCR: Enhanced genomic sequencing and in vivo footprinting. _Proc. Natl. Acad. Sci. U.S.A._**89**, 1021-1025 \(1992). 5. Pfeifer, G. P., Tanguy, R. L., Steigerwald, S. D. \& Riggs, A. D. In vivo footprint and methylation analysis by PCR-aided genomic sequencing: Comparison of active and inactive $X$ chromosomal DNA at the CpG island and promoter of human PGK-1._Genes Dev._ **4**, 1277-1287 (1990).

\section{Figures}

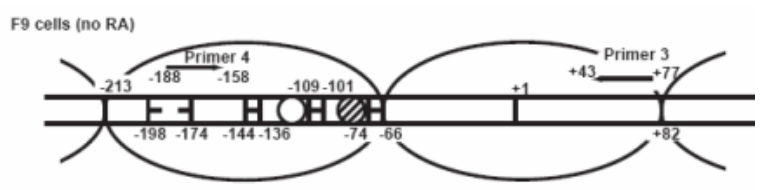

F9 cells (treated with RA for $24 \mathrm{~h}$ )
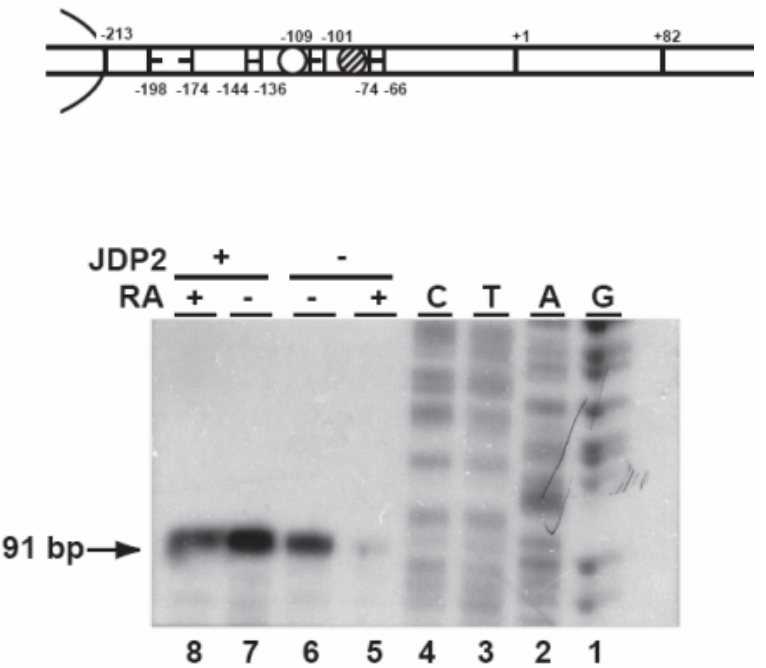

Figure 1

Mononucleosomal DNA was purified and allowed to anneal to radiolabled primer 3. Extension and LMPCR allowed the detection of extended products. A sequencing gel provided size markers. The upper schematic illustration shows the positions of nucleosomes in the absence (upper drawing) and presence of (lower drawing) of retinoic acid (RA). Small circles, Putative Sp-1-binding sites; small hatched circles, putative CTF-binding sites; short arrows, retinoic acidand R1A- response elements (a pair of upstream DREs) ${ }^{\wedge} 4^{\wedge}$. 